\title{
The Influence Of Market Orientation, Flexibility And Job Satisfaction On Corporate Entrepreneurship
}

Mandla Adonisi, Gordon Institute of Business Science, South Africa R. van Wyk, Gordon Institute of Business Science, South Africa

\begin{abstract}
The profound dynamic changes that the South African business environment is going through and the low level of business development in the country begs for entrepreneurial innovation. This paper is an investigation into the relationship of corporate entrepreneurship with the organizational variables of marketing, flexibility and job satisfaction. These relationships are investigated in a sample of 333 managers in three different industries in South Africa. The relationships between corporate entrepreneurship and biographic variables were examined by means of Spearman correlation. Pearson-product moment correlation explored the association between corporate entrepreneurship and the organizational variables. The empirical results show significant relationships with different market orientation, flexibility, and job satisfaction factors. We suggest that organizations should nurture their corporate entrepreneurial strategies by fostering its orientation towards marketing, flexibility and job satisfaction.
\end{abstract}

Keywords: Corporate Entrepreneurship; Marketing; Flexibility; Job Satisfaction

\section{INTRODUCTION}

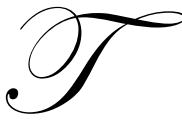

he cultivation of the entrepreneurial environment of a firm is widely recognized as a key success factor to secure the growth and survival of an organization. For a rapid developing country such as South Africa, there is a rather low level of entrepreneurship (Alexander, 2011). The Global Entrepreneurship Monitor consistently rates South Africa's entrepreneurial activity as poor (Luiz \& Mariotti, 2011). The South African business environment has been through profound and dynamic changes, some of which have been exacerbated by the economic recession, and continue to have devastating effects on the economy. Although South Africa has been able to lessen the impact of the recession, many industries are still reeling under its effects. Additionally, the entry of international companies, such as Wal-Mart, has created new challenges in the retail sector. The nurturing of entrepreneurship at the corporate level in South Africa is something that has to be actively addressed to advance economic growth and aid in eliminating the high unemployment crisis the country faces.

The new millennium has brought increased global competitiveness and challenges. Companies that participate in global markets need to continuously explore methods of gaining advantage by incessantly providing superior goods and services to customers in the face of competitors (Gabberty \& Vambery, 2008). Business leaders should anticipate the environmental changes that are taking place in the landscape in which they operate and respond swiftly and accurately in order to survive (Jafari, Rezaeernour, Mazdeh \& Hooshmandi, 2011). Management plays a vital role in facilitating the process of corporate entrepreneurship and fostering of entrepreneurial talent in creating real value for stakeholders (Kenney, Khanfar \& Kizer, 2010).

In order to survive in the global market and advance entrepreneurship, it is necessary to explore the different variables that seem to play a progressive role in the execution thereof. There is a need for research to provide solutions to the process of instilling corporate entrepreneurial behaviours (Thornberry, 2003). Key factors in entrepreneurial development and global competitiveness are market orientation (Barrett \& Weinstein, 1998; 
Jaworski \& Kohli, 1996; and Kohli, Jaworski \& Kumar, 1993), organizational flexibility (Barrett \& Weinstein, 1998), and job satisfaction (Jaworski \& Kohli, 1996). In the current study, these factors are explored in a South African context.

\section{LITERATURE REVIEW}

Management should encourage the development of corporate entrepreneurship and its influence on innovation and performance (Hornsby, Naffziger, Kuratko \& Montagno, 1993, and Morris, Kuratko \& Covin, 2008). The core of corporate entrepreneurship is to establish an environment that initiates and promotes innovative corporate intelligence (Antoncic \& Hisrich, 2001; Goosen, de Coning \& Smit, 2002; and Hornsby, Kuratko \& Zahra, 2002). Corporate entrepreneurship preserves the strategic renewal of a business, thus ensuring its innovativeness and profitability (Drucker, 2007, and Morris et al., 2008) and a sustained pioneering advantage (Rivas, 2007).

The many definitions of corporate entrepreneurship acknowledge the following elements (Sharma \& Chrisman, 1999):

- $\quad$ the re-development of new businesses within the mother company

- $\quad$ the transformation of key areas in a business

- the renewal of an existing business

Businesses have to take part in some form of entrepreneurial activity to be able to operate effectively in competitive markets and create value (Zimmerman, 2010). The link between corporate entrepreneurship and market orientation is seen as the basis for sustaining innovation and maintaining a competitive advantage (Barrett \& Weinstein, 1998; Lee \& Hsieh, 2010; and Weerawardena \& Cass, 2004). It is a necessity for sustained economic development (Oudan \& Luparelli, 2011). Market orientation refers to the organization-wide responsiveness to the generation and dissemination of market intelligence (Jaworski \& Kohli, 1996, and Kohli \& Jaworski, 1990) with superior customer value as its primary objective (Jiménez-Zarco, Martinez-Ruiz \& Izquierdo-Yusta, 2009, and Weerawardena \& Cass, 2004). Market orientation implies doing innovative and novel things in response to market conditions (Narver \& Slater, 1990, and Slater \& Narver, 1994). It is the maintenance of a culture of sustainable advantage by continuously providing superior value for customers.

The role of global marketing is becoming more complex as firms have to cater for a diversity of consumers from different social and cultural backgrounds (Gabberty \& Vambery, 2008). Marketing has evolved from improved production processes to product development and finally for the advancement of quality of life (Kotler, 2003). In total, it contributes to consumer well-being (Leelakulthanit \& Hongcharu, 2011). The strategy of market orientation is the reaction to the dynamics of altering challenging economic environments (Akonkwa, 2009). Marketing is also a method of building lasting and mutually beneficial relationships between firms and consumers (Nwakanma \& Jackson, 2007). Innovative marketing practices enable businesses to cope with adverse circumstances, declining sales, and intense competition (Kotler, 2003). Different studies confirm the significant positive relationship between market orientation and corporate entrepreneurship (Barrett \& Weinstein, 1998; Liu, Luo \& Shi, 2002; and Luo, Zhou \& Liu, 2003).

As companies grow and become competitive, a level of control has to be implemented by means of policies, leading to bureaucratic procedures (Zimmerman, 2010). However, competitive organizations operate in complex environments and therefore need flexible planning systems to cope with frequent changes (Kukalis, 1989). Firms with low flexibility are more rigid and bureaucratic in their administrative and operational procedures (Barrett \& Weinstein, 1998; Khandwalla, 1977; and Miles \& Snow, 1978). Although different labels have been used to characterize flexible organizations, a common feature is that they have decentralized decision-making and are adaptable and versatile. They allow employees to take self-control.

Innovative entrepreneurial ventures need flexible functional design and operations to facilitate frankness in the exchange of information (Jaworski \& Kohli; 1996, and Van de Ven \& Poole, 1995). The facilitation of corporate entrepreneurship is restricted when rules and regulations are strictly adhered to, thus limiting the spontaneity of the 
process (Chung \& Gibbons, 1997). To survive and prosper in turbulent environments, organizations must respond with speed and flexibility when market opportunities arise. However, flexibility in the production process has to be policed with sophisticated cost accounting practices (Venieris \& Cohen, 2008). In order to spread marketplace information effectively one needs flexible systems to filter through cross-functional boundaries (Miles \& Snow, 1978, and Child \& McGrath, 2001). Research confirms a significant positive correlation between corporate entrepreneurship and flexibility (Barrett \& Weinstein, 1998, and Barringer \& Bluedorn, 1999).

Satisfaction in the workplace is an international concern for businesses (Wagman \& Villarreal, 2008). Job satisfaction is one of the most widely and frequently studied variables in the field of organization behavior (Luthans, 1998, and Robbins, 2005). It is defined as "a pleasurable or positive emotional state, resulting from the appraisal of one's job experiences" (Locke, 1983:1300). Job satisfaction, in its broadest sense, refers to a person's general attitude toward the job or specific dimensions of the job (Knoop, 2001, and Robbins, 2005). Weiss, Dawis, England and Lofquist (1967) refer to job satisfaction as the actual satisfaction of the individual with intrinsic and extrinsic reinforcement. Different studies confirm the importance of the relationship between entrepreneurship and job satisfaction. A significant positive relationship was found between corporate entrepreneurship and job satisfaction (Jaworski \& Kohli, 1996) and between intrinsic job satisfaction and entrepreneurial attitude (Van Wyk, Boshoff \& Bester, 2003). It is also indicated that entrepreneurs score significantly higher on job satisfaction than individuals that are employed (Katz, 1993, and Weaver \& Franz, 1992).

Seen in the light of the importance of corporate entrepreneurship for business growth and economic growth, this study investigates the relationship of corporate entrepreneurship with biographic variables and the organizational variables of market orientation, job satisfaction, and flexibility. The research questions are:

Research Question 1: What is the relationship of corporate entrepreneurship with biographic variables?

Research Question 2: What is the relationship between corporate entrepreneurship, market orientation, job satisfaction, and flexibility?

Research Question 3: To what extend does market orientation, job satisfaction, and flexibility predict corporate entrepreneurship?

\section{METHODOLOGY}

A self-administered questionnaire was sent to a non-random quota convenience sample. The sample represented four different economic sectors in South Africa. The participants represented managers and supervisors from life insurance, information and technology, tertiary education, and transport sectors. The questionnaire consisted of an introductory letter, biographic questions, as well as instruments measuring corporate entrepreneurship, market orientation, job satisfaction, and flexibility. Of the 396 questionnaires received, 36 were discarded due to incomplete items in the psychometric questions. The analyses were done on 333 participants.

\section{Participants}

The non-random convenience sample from four different economic sectors gave a total of 266 participant from life insurance, 33 from information technology, 26 from a university of technology and eight from a transport parastatal. Due to incomplete items in the psychometric instruments, only 333 of the 396 responses were used, consisting of 144 males and 187 females. Two individuals did not indicate their gender. The age range of the participants was between 21 and 70 years (mean $=36.66$ and standard deviation $=9.26$ years). The majority of the participants (58.2 percent) were married (194), 82 unmarried, seven widowed, 36 divorced, 11 co-habiting, one estranged, and two individuals did not indicate their marital status. The home language of most of the participants was English (202), followed by Afrikaans (86), and other African languages (45). The respondents were mainly South African (326), non-South African (4), and not indicated (3). The academic qualifications of the participants varied from Master's degree (17), Honours degree (33), Bachelor's degree (38), post-school certificate/diploma (105), Grade 12 (87), secondary school without Grade 12 (46), and no indication of academic training (7). 


\section{Measuring Instruments}

Psychometric instruments are not always portable between cultures, reducing the validity of the instrument (De Klerk, Boshoff \& Van Wyk, 2009; Meiring, Van de Vijver \& Rothmann, 2006; Van Eeden \& Mantsha, 2007; Van Wyk \& Adonisi, 2011; and Van Wyk, Boshoff \& Owen, 1999). Principal factor analysis with direct quartimin rotation of the axis was applied in the evaluation of each of the psychometric instruments. This was followed by a confirmatory factor analysis (Adonisi, 2003, and Van Wyk \& Adonisi, 2011). Alpha coefficients of the factors in the different instruments are reported in the description of each instrument.

The Corporate Entrepreneurial Assessment Instrument (CEAI) was used to measure corporate entrepreneurship (Hornsby et al., 2002). The 48-item Likert-type scale, varying between (1) strongly disagree and (5) strongly agree, had 11 negatively worded items. The principal factor analysis in the current study showed an eight-factor solution for the CEAI. The factors had acceptable Alpha coefficients (reported in brackets) named work discretion (0.84), management support and risk-taking (0.82), rewards and reinforcement (0.75), innovative initiatives (0.84), financial support (0.73), sufficient time (0.76), organizational boundaries $(0.81)$, and inadequate time $(0.67)$.

The MARKOR market orientation instrument (Kohli et al., 1993) measured three factors - intelligence generation, intelligence dissemination, and responsiveness - on a 32-item seven-point Likert scale. Confirmatory factor analysis showed the goodness-of-fit indices of the three factors as between 0.656 and 0.740 . An investigation into the factor structure in the current study, by means of principal factor analysis, showed a three-factor solution. The factors were named intelligence generation (0.81), inertia (0.83), and responsiveness $(0.74)$.

The organizational flexibility scale of Khandwalla (1987) measured flexibility. This scale is reported as one factor and the psychometric properties were not provided (Khandwalla, 1987). Principal factor analysis of the current study revealed a two-factor solution - formality and authoritarianism - with Cronbach Alpha coefficients of 0.81 and 0.64 , respectively.

Job satisfaction was measured by Minnesota Job Satisfaction Questionnaire (Weiss et al., 1967) consisting of 20 items, measured on a five-point Likert scale varying from (1) very dissatisfied to (5) very satisfied. The instrument consists of the two factors of intrinsic and extrinsic job satisfaction, with Alpha coefficients of 0.86 and 0.80 , respectively. In the current study, a principal factor analysis showed two factors - extrinsic (0.86) and intrinsic job satisfaction (0.85). Table 1 is a summary of the different factors identified in the factor analyses.

Table 1: Description of Different Factors as Applied in Statistical Analyses

\begin{tabular}{ll}
\hline Variable & Description \\
\hline CE1 & Corporate Entrepreneurship: work discretion \\
CE2 & Corporate Entrepreneurship: management support and risk acceptance \\
CE3 & Corporate Entrepreneurship: rewards/reinforcement \\
CE4 & Corporate Entrepreneurship: innovative initiatives \\
CE5 & Corporate Entrepreneurship: financial support \\
CE6 & Corporate Entrepreneurship: sufficient time \\
CE7 & Corporate Entrepreneurship: organizational boundaries \\
CE8 & Corporate Entrepreneurship: inadequate time \\
MO1 & Market orientation: intelligence generation \\
MO2 & Market orientation: inertia \\
MO3 & Market orientation: responsiveness \\
F1 & Flexibility: formality \\
F2 & Flexibility: authoritarianism \\
JS1 & Job satisfaction: extrinsic \\
JS2 & Job satisfaction: intrinsic \\
\hline
\end{tabular}




\section{EMPIRICAL RESULTS}

The first research question investigating the relationships between the eight corporate entrepreneurship factors and the biographic variables was investigated by means of Spearman correlation coefficients (Table 2).

Table 2: Results from Calculation of Spearman Correlation Coefficients between Corporate Entrepreneurship and Biographic Variables and for the Total Observations

\begin{tabular}{|l|c|c|c|c|c|c|c|c|}
\hline $\begin{array}{l}\text { Biographic } \\
\text { Variable }\end{array}$ & CE1 & CE2 & CE3 & CE4 & CE5 & CE6 & \multirow{2}{*}{ CE7 } & CE8 \\
\hline Age & 0.09 & -0.05 & -0.04 & 0.04 & 0.16 & -0.02 & -0.08 & 0.01 \\
& 0.1245 & 0.3462 & 0.464 & 0.502 & 0.004 & 0.7355 & 0.1435 & 0.933 \\
\hline No of years & -0.05 & -0.10 & -0.09 & -0.00 & -0.00 & -0.09 & 0.06 & -0.15 \\
in org & 0.4011 & 0.0757 & 0.0970 & 0.9531 & 0.9780 & 0.1284 & 0.3051 & 0.0076 \\
\hline No years in & -0.05 & -0.05 & -0.12 & 0.01 & 0.07 & -0.04 & -0.00 & -0.08 \\
job & 0.3392 & 0.3696 & 0.0324 & 0.8648 & 0.1915 & 0.5033 & 0.9491 & 0.1663 \\
\hline Work hours & 0.12 & 0.04 & 0.09 & -0.06 & -0.06 & -0.23 & 0.05 & -0.07 \\
p week & 0.0264 & 0.4787 & 0.0929 & 0.2621 & 0.2587 & 0.0001 & 0.3357 & 0.1942 \\
\hline No of days & -0.05 & -0.03 & -0.08 & -0.08 & -0.00 & 0.01 & 0.12 & -0.07 \\
vacation & 0.3340 & 0.6549 & 0.1441 & 0.1687 & 0.9963 & 0.9096 & 0.0270 & 0.2203 \\
\hline
\end{tabular}

The Spearman correlations showed only three significant correlations at the 95 percent level of confidence. A significant positive correlation was found between age and financial support. Significant negative correlations were indicated between number of years in the organization and inadequate time and hours of work per week and (sufficient time).

The second research question, investigated by means of Pearson Product Moment correlations, relates to the relationships between corporate entrepreneurship and the organizational variables of market orientation, job satisfaction, and flexibility (Table 3).

Table 3 is a summary of the inter-correlations among all the variables. The significant correlations vary from very low $(r=-0.14, p<0.0085)$ to the high association between innovative initiatives (CE4) and responsiveness $(\mathrm{MO} 3)(r=0.48 p<0.0001)$. It is interesting to see that the corporate entrepreneurial factors of sufficient (CE6) and inadequate time (CE8) did not correlate significantly with any of the organizational variables, with the exception of extrinsic job satisfaction and inadequate time. All the other corporate entrepreneurial factors correlated significantly with the market orientation, flexibility and job satisfaction scales, with the exception of work discretion (CE1) and the market orientation scales of inertia (MO2) and responsiveness (MO3), as well as organizational boundaries (CE7) and authoritarianism (F2). It is important to note that a number of organizational factors were significantly negatively related to the corporate entrepreneurial subscales.

Table 3: Pearson Product Moment Correlations between Corporate Entrepreneurship and Market Orientation, Job Satisfaction and Flexibility $(N=333)$

\begin{tabular}{|l|c|c|c|c|c|c|c|c|}
\hline Variable & CE1 & CE2 & CE3 & CE4 & CE5 & CE6 & CE7 & CE8 \\
\hline MO1 & 0.26 & 0.38 & 0.33 & 0.33 & 0.23 & -0.03 & -0.33 & 0.06 \\
& 0.0001 & 0.0001 & 0.0001 & 0.0001 & 0.0001 & 0.5393 & 0.0001 & 0.2964 \\
\hline MO2 & -0.07 & -0.23 & -0.23 & -0.46 & -0.26 & 0.03 & 0.23 & -0.11 \\
& 0.2261 & 0.0001 & 0.0001 & 0.0001 & 0.0001 & 0.6550 & 0.0001 & 0.0479 \\
\hline MO3 & 0.03 & 0.34 & 0.25 & 0.48 & 0.35 & -0.02 & -0.16 & -0.04 \\
& 0.6186 & 0.0001 & 0.0001 & 0.0001 & 0.0001 & 0.7780 & 0.0043 & 0.4498 \\
\hline F1 & 0.26 & 0.33 & 0.29 & 0.34 & 0.21 & -0.03 & -0.26 & -0.03 \\
& 0.0001 & 0.0001 & 0.0001 & 0.0001 & 0.0001 & 0.6479 & 0.0001 & 0.6247 \\
\hline F2 & -0.22 & -0.24 & -0.26 & -0.24 & -0.14 & -0.00 & 0.06 & -0.11 \\
& 0.0001 & 0.0001 & 0.0001 & 0.0001 & 0.0085 & 0.9790 & 0.2956 & 0.0427 \\
\hline JS1 & 0.45 & 0.29 & 0.62 & 0.36 & 0.15 & 0.07 & -0.40 & 0.17 \\
& 0.0001 & 0.0001 & 0.0001 & 0.0001 & 0.0047 & 0.2080 & 0.0001 & 0.0026 \\
\hline JS2 & 0.34 & 0.19 & 0.44 & 0.29 & 0.16 & -0.04 & -0.30 & -0.04 \\
& 0.0001 & 0.0005 & 0.0001 & 0.0001 & 0.0027 & 0.4355 & 0.0001 & 0.0529 \\
\hline
\end{tabular}


Table 4 is a summary of the prediction of the corporate entrepreneurial scales. None of the independent variables entered the prediction for $\mathrm{CE} 6$, sufficient time.

Table 4: Results of Multiple Regression Analysis with Corporate Entrepreneursial Factors as Dependent Variables

\begin{tabular}{|c|c|c|c|c|}
\hline Variable & $\mathbf{F}(\mathbf{d f})$ & $P$ & $\mathbf{R}^{2}$ & $\mathbf{C}(\mathbf{p})$ \\
\hline \multicolumn{5}{|c|}{ Work discretion (CE1) } \\
\hline JS1 & $83.79(1 ; 332)$ & 0.0001 & 0.2020 & 16.1612 \\
\hline MO1 & $4.85(2 ; 331)$ & 0.0284 & 0.2136 & 13.1649 \\
\hline $\mathrm{MO} 3$ & $5.01(3 ; 330)$ & 0.0259 & 0.2254 & 10.0616 \\
\hline \multicolumn{5}{|c|}{ Management support (CE2) } \\
\hline MO1 & $55.03(1 ; 332)$ & 0.0001 & 0.1426 & 45.2903 \\
\hline F1 & $19.15(2 ; 331)$ & 0.0001 & 0.1896 & 26.7649 \\
\hline MO3 & $14.80(3 ; 330)$ & 0.0001 & 0.2245 & 13.5351 \\
\hline F2 & $11.57(4 ; 329)$ & 0.0008 & 0.2509 & 3.9959 \\
\hline \multicolumn{5}{|c|}{ Rewards/reinforcement (CE3) } \\
\hline JS1 & $210.22(1 ; 332)$ & 0.0001 & 0.3884 & 9.6219 \\
\hline MO3 & $8.21(2 ; 331)$ & 0.0044 & 0.4033 & 3.3993 \\
\hline \multicolumn{5}{|c|}{ Innovative initiatives (CE4) } \\
\hline $\mathrm{MO3}$ & $100.95(1 ; 332)$ & 0.0001 & 0.2337 & 64.4358 \\
\hline JS1 & $32.11(2 ; 331)$ & 0.0001 & 0.3017 & 31.5503 \\
\hline $\mathrm{MO} 2$ & $19.69(3 ; 330)$ & 0.0001 & 0.3411 & 13.2988 \\
\hline F1 & $9.25(4 ; 329)$ & 0.0025 & 0.3592 & 6.0183 \\
\hline \multicolumn{5}{|c|}{ Financial support (CE5) } \\
\hline MO3 & $45.34(1 ; 332)$ & 0.0001 & 0.1205 & 9.2041 \\
\hline F1 & $6.27(2 ; 331)$ & 0.0128 & 0.1369 & 4.9021 \\
\hline \multicolumn{5}{|c|}{$\begin{array}{l}\text { Sufficient time (CE6) } \\
\text { No entries }\end{array}$} \\
\hline \multicolumn{5}{|c|}{ Organizational boundaries (CE7) } \\
\hline JS1 & $63.34(1 ; 332)$ & 0.0001 & 0.1606 & 19.6187 \\
\hline MO1 & $15.87(2 ; 331)$ & 0.0001 & 0.1991 & 5.6242 \\
\hline \multicolumn{5}{|c|}{ Inadequate time (CE8) } \\
\hline JS1 & $9.23(1 ; 332)$ & 0.0001 & 0.0271 & 15.2254 \\
\hline JS2 & $20.56(2 ; 331)$ & 0.0001 & 0.0573 & 6.5496 \\
\hline
\end{tabular}

The predictions of the different corporate entrepreneurial scales varied from very weak, inadequate time (CE8) 5.73 percent, to strong rewards/reinforcement (CE3) 40.33 percent. All the market orientation, flexibility and job satisfaction subscales played a role in the predictions relative to the corporate entrepreneurial scales.

\section{DISCUSSION}

The findings support the important relationship of market orientation, flexibility, and job satisfaction with corporate entrepreneurship. Senior management play a key role in influencing the corporate entrepreneurial process and should take note of the role that market orientation, flexibility, and job satisfaction play in facilitating the process. Applying market orientation policies with flexible strategies and procedures, culturing a job satisfaction environment, may assist businesses in facing intrapreneurial challenges. By putting these policies into operation, new ventures can be developed within businesses.

\section{IMPLICATIONS}

Corporate entrepreneurship and economic growth are best served by the collaborative relationship between market orientation, flexibility and job satisfaction. The implication for South African businesses is to upgrade their innovative expertise on a continuous basis. Employees are critical in the design, production, and marketing of products. A flexible operational culture with a vigilant market orientation and the experience of job satisfaction is crucial to the creation and sustainment of corporate entrepreneurial cultures. 


\section{SUGGESTIONS FOR FUTURE RESEARCH}

The findings of the current study can only be generalized to the sectors in the South African economy that it represents. It is recommended that the current study be duplicated in other economic sectors and countries. Future studies should also investigate alternative variables that could play a role in the development of intrapreneurial efforts in businesses.

\section{CONCLUSIONS}

The current study throws more light on some of the contributing factors of the different facets of corporate entrepreneurship. This study is unique in that eight corporate entrepreneurial factors are predicted by means of marketing orientation, flexibility, and job satisfaction. To stimulate the South African economy, management should pay attention to the fundamental role that an active market orientation, flexible operations and the nurturing of job satisfaction play in the development of intrapreneurship.

\section{AUTHOR INFORMATION}

Mandla Adonisi, $\mathrm{PhD}$ is a senior lecturer at the Gordon Institute for Business Science in the areas or Organization Development, Leadership and Strategy. Dr Adonisi has previously lectured at the Wits Business School and the Public Development Management School. He is a visiting lecturer at the School for Business Leadership, UNISA, and teaches Change Management on the Harvard/WBS Senior Executive Program. He is a lead facilitator on the Leadership Development Program run by the Agricultural Economics Department at the University of Zimbabwe. In 1992, Mandla was awarded the British Council Fellowship for Post-graduate studies in Business Administration at Aston University (UK). E-mail: adonisim@gibs.co.za

René van Wyk, PhD is an industrial psychologist, registered at the South African Health Professions Council. She is author of numerous peer-reviewed articles in organizational behavior. She has supervised a number of masters' and doctoral students and has developed course material for a doctoral program in organizational behavior. E-mail: vanwyk.rene@gmail.com. Corresponding author.

\section{REFERENCES}

1. Adonisi M, (2003). The Relationship Between Corporate Entrepreneurship, Market Orientation, Organisational Flexibility and Job Satisfaction. Doctoral dissertation. Pretoria: University of Pretoria.

2. Akonkwa, D.B . (2009). Is market orientation a relevant strategy for higher education institutions? Context analysis and research agenda. International Journal of Quality and Services Sciences, 1(3):311-333.

3. Alexander, A. (2011). Entrepreneurship in South Africa: Improving Access to Finance. MBA Thesis. Massachusetts: Massachusetts Institute of Technology.

4. Antoncic, B. \& Hisrich, R.D. (2001). Intrapreneurship: Construct refinement and cross-cultural validation. Journal of Business Venturing, 16:495-527.

5. Barrett, H. \& Weinstein, A. (1997). Corporate entrepreneurship, the marketing mix, and business performance. Conference of the Academy of Marketing Science: 144-150.

6. Barringer, M.S. \& Bluedorn, A. G. (1999). A theoretical exploration of the adoption and design of flexible benefit plans: A case of human resource innovation. Academy Management Review, 23:305-324.

7. Child, J \& McGrath, R.G. (2001). Organizations unfettered: Organizational form in an informationintensive economy. Academy of Management Journal, 44(6):1135-1148.

8. Chung, L. \& Gibbons, P.T. (1997). Corporate entrepreneurship: The roles of ideology and social capital. Group and Organisation Management, 22:10-30.

9. De Klerk, J.J., Boshoff, A.B., \& Van Wyk, R. (2009). Measuring meaning in life in South Africa: Validation of an instrument developed in the USA. South African Journal of Psychology, 39(3):314-325.

10. Drucker,P.F (2007) Innovation and Entrepreneurship ( $2^{\text {nd }}$ ed.). Burlington: Butterworth-Heinemann.

11. Gabberty, J.W. \& Vambery, R.G. (2008). How technological determinism shapes international marketing. International Business \& Economics Research Journal, 7(1):19-27. 
12. Goosen, C.J., De Coning, T.J., Smit, E. V d M. (2002). The development of a factor based instrument to measure corporate entrepreneurship: A South African perspective. South African Journal of Business Management, 33(3):39-51.

13. Hornsby, J.S., Kuratko, D.F. \& Zahra, S.A. (2002). Middle managers' perception of the internal environment for corporate entrepreneurship: assessing a measurement scale. Journal of business Venturing, 17:253-273.

14. Hornsby, J.S. \& Naffziger, D.W., Kuratko, D., \& Montagno, R. (1993). An interactive model of the corporate entrepreneurship process. Entrepreneurship Theory and Practice, 17(2):29-37.

15. Jafari, M., Rezaeernour, J., Mazdeh, M \& Hooshmandi, A. (2011) Development and evaluation of a knowledge risk management model for project-based organisations. Management Decision, 49(3):309-329.

16. Jaworski, B. J. \& Kohli, A. K. (1996). Market orientation: antecedents and consequences. Journal of Marketing, 57:53-70.

17. Jiménez-Zarco, A., Martinez-Ruiz. M. \& Izquierdo-Yusta, A. (2011) The impact of market orientation dimensions on client cooperation in the development of new service innovations. European Journal of Marketing, 45(1/2):43-67.

18. Katz, J. (1993). How satisfied are the self-employed: A secondary analysis approach. Entrepreneurship Theory and Practice, 17(3):35-51.

19. Kenney, M.G. Khanfar, N.M. \& Kizer, L.E. (2010). Practitioner perspectives of information technology industry intrapreneurship: An exploratory study. International Journal of Management \& Information Systems, 14(1):35-39.

20. Khandwalla, P. N. (1977). The Design of Organisations. New York: Harcourt.

21. Khandwalla, P.N. (1987). Generation of pioneering-innovative management: Some Indian evidence. Organization Studies, 8(1):39-59.

22. Knoop, R. (2001). Locus of control as moderator to job characteristics, job involvement and job attitudes. Psychological Reports, 48:519-525.

23. Kohli, A.K. \& Jaworski, B.J. (1990). Market orientation: The construct, research propositions, and managerial implications, Journal of Marketing, 54(2):1-18.

24. Kohli, A.K., Jaworski, B.J. \& Kumar, A. (1993). Markor: A measure of market orientation. Journal of Marketing Research, 30(4):467-477.

25. Kotler, P. (2003). Marketing Management (1 $1^{\text {th }}$ ed.). Englewood Cliffs, NJ: Prentice-Hall.

26. Kukalis, S. (1989). The relationship among firm characteristics and design of strategic planning systems in large organizations. Journal of Management, 15(4):565-579.

27. Lee, J. \& Hsieh, C. (2010). A research in relating entrepreneurship, marketing capability, innovative capability and sustained competitive advantage. Journal of Business \& Economics Research, 8(9):109-119.

28. Leelakulthanit, O. \& Hongcharu, B. (2011). Marketing for life in the economic recession time. International Business \& Economics Research Journal, 10(4):57-66.

29. Liu,S.S., Luo, X, \& Shi, Y. (2002). Integrating customer orientation, corporate entrepreneurship, and learning orientation in organisation-in-transition: An empirical study. International Journal of Research in Marketing, 19:367-382.

30. Locke, E.A. (1983). The nature and causes of job satisfaction. In Marvin D. Dunette (Ed.). Handbook of Industrial and Organizational Psychology: 1297-1350. New York: John Wiley.

31. Luiz, J. \& Mariotti, M. (2011). Entrepreneurship in an emerging and culturally diverse economy: A South African survey of perceptions. South African Journal of Economic and Management Sciences, 14(1):47-65.

32. Luo, W., Zhou, L., \& Liu, S.S. (2005). Entrepreneurial firms in the context of China's Transition economy: An integrative framework and empirical examination. Journal of Business Research, 58:277-284.

33. Luthans, F. (1998). Organisational Behaviour ( $8^{\text {th }}$ ed.). Singapore: Irwin/McGraw-Hill.

34. Meiring, D., Van de Vijver, F.J.R. \& Rothmann, S. (2006). Bias in an adapted version of the 15FQ+ in South Africa. South African Journal of Psychology, 36:340-356.

35. Miles, R.E. \& Snow, C. (1978). Organizational Strategy and Process. New York: McGraw- Hill.

36. Morris, M.H., Kuratko, D.F. \& Covin, J.G. (2008). Corporate Entrepreneurship innovation (2 ${ }^{\text {nd }}$ ed.). Mason, OH: Thomson.

37. Narver, J.C., \& Slater, S.F. (1990). The effect of a market orientation on business profitability. Journal of Marketing, 54(4):20-35. 
38. Nwakanma, H. \& Jackson, A.S. (2007). Relationship marketing: An important tool for success in the marketplace. Journal of Business \& Economics Research, 5(2):55-64.

39. Oudan, R. \& Luparelli, A.N. (2011). Marketing and growth strategies for emerging economies: A casestudy of Trinidad and Tobago. International Business \& Economics Research Journal, 10(10):71-78.

40. Rivas, R.M. (2007). A study of corporate venturing and sustainability of first mover advantages during technological disruption in the U.S. mobile wireless data industry. Review of Business Information Systems, 11(4):97-104.

41. Robbins, S.P. (2005). Organizational Behavior (11 ${ }^{\text {th }}$ ed.). Englewood Cliffs, NJ: Prentice Hall.

42. Sharma, P. \& Chrisman, J.J. (1999). Toward a reconciliation of the definitional issues in the field of corporate entrepreneurship. Entrepreneurship Theory Practice. 23(3):11-27.

43. Slater, S.F., \& Narver, J.C. (1994). Does competitive environment moderate the market orientationperformance relationship? Journal of Marketing, 58(1):46-55.

44. Thornberry, N. (2003). Corporate entrepreneurship: Teaching managers to be entrepreneurs. The Journal of Management Development, 22(4):329-345.

45. Van de Ven, A.H. \& Poole, M.S. (1995). Explaining development and change in organisations. Academy of Management Review, 20:510-540.

46. Van Eeden, R., \& Mantsha, T.R. (2007). Theoretical and methodological considerations in the translation of the 16PF into an African language. South African Journal of Psychology, 37:62-81.

47. Van Wyk, R \& Adonisi, M. (2011). An eight-factor solution for the Corporate Entrepreneurship Assessment Instrument. African Journal of Business Management, 5(1): 3047-3055.

48. Van Wyk, R., Boshoff, A.B. \& Bester, C.L. (2003). Entrepreneurial attitudes: What are their sources? South African Journal of Economic Management Sciences, 6(1):1-24.

49. Van Wyk, R., Boshoff, A.B. \& Owen, R. (1999). Construct validity of psychometric instruments developed in the United States, when applied to professional people in South Africa. South African Journal of Economic and Management Sciences, SSI:1-72.

50. Venieris, G. \& Cohen, S. (2008). Flexibility in manufacturing and activity based costing: Modeling the interrelationships. Journal of Applied Business Research, 24(2):81-96.

51. Wagman, G.R. \& Villarreal, J.R. (2008). A conspectus of job satisfaction: A cross-cultural analysis of Mexican and American employees. International Business \& Economics Research Journal, 7(7):129-135.

52. Weaver, C. N. \& Franz, R. (1992). Work-related attitudes of entrepreneurs, public and private employees. Psychological Reports, 70:387-390.

53. Weerawardena, J. \& O’Cass, A. (2004). Exploring the characteristics of the market-driven firms and antecedents to sustained competitive advantage. Industrial Marketing Management, 33:419-428.

54. Weiss, D.J. Dawis, R., England, G.P. \& Lofquist, L.H. (1967). Manual of the Minnesota Satisfaction Questionnaire. St. Paul: University of Minnesota, Industrial Relations Center.

55. Zimmerman, J. (2010). Corporate entrepreneurship at GE and Intel. Journal of Business Case Studies, 6(5):77-81. 
NOTES 